\title{
The Sharia Compliance of Islamic Multi Contract in Islamic Banking [1]
}

\author{
Muhammad Maksum \\ Syarif Hidayatullah \\ State Islamic University Jakarta, Indonesia \\ muhammad.maksum@uinjkt.ac.id
}

\begin{abstract}
Contract (akad) in Islamic banking transactions differs from the one in conventional banking. Although both produce the same product with the same name, but with certain contracts, it becomes distinct in characteristics. Some products are even a combination of multiple contracts (multi contract). By comparing the Sharia standards specified in the fatwa by the National Sharia Board (Dewan Syariah Nasional/DSN), Indonesian Ulema Council, with multi contract practices in Islamic banking, the results of the study prove to still find prohibited elements in the practices, especially usury. Here, the contract practices do not comply with the provisions mentioned in the fatwa. To avoid such usury, profit sharing system is an alternative to take and to promote.
\end{abstract}

Keywords-Multi Contract; Fatwa; Islamic Banking; Usury; Profit Sharing;

\section{INTRODUCTION}

Multi contract will be considered as an alternative if products in conventional system are adjusted to those in Sharia due to the inadequacy of simple contracts to answer modern financial products. (Maksum, 2013) In addition, the modification of the contract aims at avoiding usury considering that Islamic banking faces difficulties to create products that conform to Sharia. [2] Such difficulties occur because the main activity of a bank is borrowing and lending (as intermediary), whereas the favorite product in Islamic banking is buying and selling (murabahah). In one side, time value of money is recognized. The sale and purchase by credit (muajjal), for example, with higher price than in cash is legit. In another, loan paid by credit is not incurred with additional charges even though the value of money in the present will be different from that in the future. (Siddiqui, 2010)

The Sharia provisions in finance concern with the prohibition of usury, gharar (uncertainty), and maysir (speculation)( Schoon, 2008) in which the prohibition of usury becomes the main point in Islamic banking activities. (Maksum, 2015) To this end, multi contract is an effort initiated by Islamic banking to diversify products which are free from any forms of interest. (Lewis, 2008) As a result, the contract model applied in Islamic financial products is currently a single (basith) contract, multiple contracts ('uqûd mujtami'ah), and 'uqûd muta'addidah. (Maksum, 2014)
To ensure the sophistication of Islamic banking products, the Sharia Supervisory Board (Dewan Pengawas Syariah/DPS) must be committed to conforming the products to Sharia provisions and to not siding with the interests of Islamic Financial Institutions (Lembaga Keauangan Syariah/LKS). In practice, Sharia products have an opportunity to be contaminated with prohibited elements given the fact that the society does not merely borrow or lend money, but they still expect interest in other forms. (Kuranm, 1986) It is proven that the high rate of saving in Islamic banking is positively correlated with the high rate of interest. As a consequence, the risk of customers shifting from Islamic banking to conventional banking has gradually occurred along with the declining of return rate given by the Islamic banking compared to the conventional one. (Kasri, 2009)

Such difficulties drive Islamic banking to do a trick (hilah) to avoid any forms of interest. Hilah is a method of prevention of things that are forbidden. Another reason to implement such method is an easy transaction. (al-'Imrâni, 2006) Most products in Islamic banking reflect the existence of hilah especially in multi contract products.

This study attempts to answer the conformity of multi contract practices in Islamic banking. In the meantime, its objective is to uncover the multi contract practices which are not in accordance with the provisions of Sharia by conducting interviews with some personnel in Islamic banking and members of the National Sharia Council and investigating the procedures and contracts. Here, the study will examine the procedures and contracts by comparing multi contract practices with the Sharia principles. In particular, it focuses on the practices at BNI Syariah and Bank Danamon Syariah which include murabahah product, hajj financing, Islamic pawn, letter of credit, and Islamic credit card.

\section{Multi Contract: Between Prohibition And NeEd}

Multi contract literally means more than one; more than two; or double. According to the Islamic jurisprudence, multi contract (known as al-'uqûd al-murakkabah in Arabic) is a set of multiple contracts comprised in one contract -- jointly or reciprocally-- so that all rights and obligations it incurs are seen as the legal consequences of a contract. (Al-'Imrâni, 
2006). In other terms, the multi contract is also known as al'uqûd al-murakkabah, al-'uqûd al-al-mujtami'ah, and al-'uqûd al-mukhtalithah.

Basically, the law of multi contract is not necessarily the same as the law of the contracts that construct it. The multi contract in bai' (purchase) and salaf, for instance, is clearly prohibited by the Prophet. However, if the two contracts stand alone, then both of them are allowed. Similarly, marrying two sisters at the same time is against the law, but if marrying them one by one is legally possible. Theoretically, the law of multi contract is likely to be affiliated with the law of the contract that builds it. This provision is generally applicable, whereas some hadith and other verses in Qur'an which forbid it are exceptional provisions. (Hammâd, 2005) The principle of Islamic jurisprudence states that the original law of a contract is permissible and valid; the contract may be considered invalid if a legal proposition forbids or cancels it. (Al-'Imrâni, 1955) In contrast to the majority of scholars, the Dhâhiriyyah Ulema forbid multi contract. They argue the original law of a contract is prohibited unless it is indicated by religion.

The opinions that allow multi-contract are stronger and in accordance with the new era of globalization. Here, such contract is limited due to several aspects; First, Al-Qur'an and Hadith forbid it. Prophet Muhammad has, for instance, clearly stated three forms of banned multi contract, multi contract in bai' wa salf (بيع وسلف), two contracts of bai' in one contract (بيعتين فى بيعة واحدة), and two transactions in one transaction (Hanbal, 1414.H) The basis of the prohibition, according to Imam al-Shafi'i is due to uncertainty. He points out, if someone is willing to buy a house for a hundred on one condition that he lends (salaf) a hundred to the seller, then the actual price in the sale and purchase contract is a combination of the money and the lending benefits received by the seller. The benefits themselves are not clear in size. This means that the price in the contract is not clear. (AlMuzaniy) Second, multi contract which turns into hîlah ribawi can occur in sale and purchase agreement and riba fadhl. Third, multi-contract consists of contracts in which their legal consequences are contradictory. Basically, sale and purchase is a muamalah activity that strongly has something to do with profit and loss, while salaf is a social activity that puts forward the aspect of comradeship and compassion and noble purpose. Consequently, the Malikiyah Ulema forbid multi contract in contracts with different legal provisions, such as between sale and purchase contract with ju'alah, sharf, musaqah, syirkah, qirâdh, or marriage. Another example is the incorporation of hibah and bai'. These opposing (mutadhâdah) contracts are forbidden to be collected in a single transaction.

\section{EXAMINING Multi CONTRACT Practices}

\section{A. Murabaha Practice}

Murabaha is the sale and purchase of goods at the original price with an additional agreed profit. (Rusdy, 1988) The payment of the price is completed by deferrals or, in another word, is paid off at a certain time agreed. (Dewi,
2006) With murabahah, the bank's clients buy a commodity according to certain details and expect the bank to send it to them on a specified price basis according to the agreement between the parties. (Mannan, 1997)

The Murabaha products are considered as the most dominant products in Islamic banking. Its nature of low risk and fixed return is the reason banks apply this scheme. Profits are reasonable facts in business activities, including in Islamic banking.[3] In Bank Danamon, for example, the murabaha products are used for heavy equipment purchase and finance for procurement and working capital. Similarly, BNI Syariah also uses murabaha products for working capital finance and other consumer needs.

The murabaha financing is categorized as a multicontract as it practices more than one contract. There are two possible procedures of murabaha in Islamic banking; first, the Islamic banking purchases goods from suppliers for a certain price, then the banking sells it to customers at the certain price and profit; secondly, the Islamic banking represents a customer (wakalah) to buy a certain item and on behalf of the banking, the customer sells the item to another customer at a certain price along with the banking profit.

The procedures of murabaha financing must comply with the provisions of Fatwa by the National Sharia Board No. 4/2000 on Murabaha ratified on April 1, 2000. One of the provisions that must be met include; that the traded goods are not prohibited by Islamic law; the bank purchases the goods required by customers on behalf of the bank itself and this purchase must be legitimate and free of usury; the bank must submit all matters related to the purchase --if the purchase is made by credit, for example-- ; and the bank sells the goods to the customers (buyers) with the selling price and the profit. In this regard, the bank must honestly disclose the price of goods to the customers. (DSN, 2003)

Bank Danamon Syariah uses the two procedures of murabaha. This can be seen from the provisions of murabaha financing issued by the bank. The first procedure is performed where a customer submits the Letter of Ordering Goods (Surat Permohonan Pesanan Barang/SPPB) to the bank in a form which is acceptable to the bank and has been signed by the customer no later than 5 (five) working days before the bank makes the payment to the supplier. The letter is a unity and an integral part of murabaha contract. In turn, the bank will make the payment to the supplier. Finally, the bank or the supplier on behalf of the bank hands over the goods to the customer.

The second model appears in the following clause: "In connection with the aforementioned sale of goods, the bank may authorize in writing to the customer who will act for and on behalf of the bank to buy and receive the goods ordered by the customer in accordance with the laws and regulations". If this procedure is used, then the purchase and sale of goods or assets is carried out by the customer.

According to the procedures and stages of murabaha financing, the two banks have met the provisions of the fatwa by the National Sharia Board. The key word in such financing is goods or assets financing. This means a customer must receive goods or assets instead of money. If the customer, for 
example, receives money financing, then it is not in accordance with the provisions of murabaha.

\section{B. Hajj Financing}

The contracts applied in hajj financing are ijarah and qardh. Ijarah, for instance, is selling benefits of an object and in term of lease only the benefit is leased, not the object. (alZuhaili, 1987) In this contract, a person who provides the benefits may request a change (reward). The reward here is paid as a payment for the benefit. Meanwhile, qardh is a loan contract for a customer provided that he is obliged to return the loan to the Islamic financial institution he chooses to agree with. In qardh financing, there is no justification of any additional charge to the basic loan as the charge is considered usury which is prohibited in Islam.

At the beginning of the launching, this product is known as Hajj bailout (Dana Talangan Haji), a product in which Islamic banking provides bailout for customers to pay the Hajj Operating Cost (Biaya Penyelenggaraan Ibadah Haji/BPIH) and the customers will pay back the bailout including the profit margin. This margin is calculated from the amount of bailout given to the customer. [4] In this case, the determination of the margin is not in accordance with the provisions of Sharia as it is considered as usury.[5] In addition, the margin also contradicts the fatwa the National Sharia Board No. 29/2002 ratified on June 26, 2002. The fatwa emphasizes that the margin is calculated based on services, not the amount of the bailout granted.

In fact, the practices of hajj financing are not in line with the Sharia provisions considering that the margin determination is based on the amount of bailout given to customers. Costing refers to how much the Hajj operating cost is required, not the bailout. In this regard, if it has the same arrangement, then it costs the same, although the amount of the bailout is different; some are bailed for 10 million or some are given a 5 million or 3 million bailout, for example.

\section{Pawn Products}

Islamic Pawn or rahn is holding one of the properties of the customer (rahin) as collateral (marhun) for debt/loan (marhun bih) he receives. According to Kasmir, pawn is an activity of securing valuable items to certain parties in order to obtain some money and the items will be redeemed in accordance with the agreement between the customer and the parties (pawnshop). In Islamic finance and banking, Rahn or pawn is the delivery of goods as collateral to make a loan.

In Islamic banking, another contract other than rahn, known as ijârah (lease) is applied. This is seen from some statements and practices in the field. The fatwa by the National Sharia Board mentions a maintenance charge, "the maintenance and security of the collateral (marhunn) is basically obliged to the customer (râhin), but it can also be undertaken by the pawnshop (murtahin), whereas the cost of the maintenance and security is charged to the râhin".

In practice, the Islamic banking applies some contracts such as rahn, qardh, and ijara for gold pawn. Here, the customer receives qardh financing and hands over the gold as collateral. In turn, the banks charge the maintenance of the gold based on ijarah contract. The charge is either paid daily or monthly.

The critical point of this product lies in the charge of maintenance in the rahn. This charge is actually not mentioned in the contract as rahn is essentially securing an item over a loan. The imposition of this charge is a consequence of the cost of maintenance where the pawnshop takes place. Therefore, it can more appropriately be regarded as ijârah contract. In the fatwa regarding rahn contract, ijârah contract is not explicitly mentioned as a part of it. However, in the fatwa concerning the rahn contract for gold, such contract is explicitly stated. To avoid usury, the determination of ujrah is based on the cost of securing.

\section{Letter of Credit Service}

$\mathrm{L} / \mathrm{C}$ is one of Islamic banking services to provide handling and payment service or billing in export and import activities conducted by customers. The Islamic L/C for Import activities applies the following contracts: Wakalah bil Ujrah, Qardh, Murabaha, Salam/Istishna, Mudharabah, Musyarakah, and Hawalah. [6] In terms of Export activities, it uses Wakalah bil Ujrah [7], Qardh, Mudharabah, Musyarakah and Bai'. In practice, the Islamic banking implements Mudharabah, Musyarakah, Wakalah bil Ujrah, and Qardh.

The implementation of wakalah bil ujrah independently does not cause problems. However, if it is combined with qardh, an issue regarding the legality of the imposition of charge for the $\mathrm{L} / \mathrm{C}$ financing will arise. Through these two contracts, the Islamic banking both takes care of the $\mathrm{L} / \mathrm{C}$ documents and bails out payments to other parties who become partners of the customers using the service. Here, the banks will get profit from the wakalah instead of qardh. Further, the profit is set in advance and does not refer to the percentage of the bailout given to the customers. As commonly known, the profit based on the percentage of loan has the potential to fall into usury practices, as the additional cost becomes unclear whether it is generated from wakalah or additional charge (riba fadhl) gained from the bailout (qardh).

\section{E. Credit Card Service}

Islamic credit card product is considered the most controversial issue. In Sharia, for one side, the possibility of falling into the forbidden is very high. In economic side, it can encourage the attitude of consumerism which is strictly avoided in Islam. However, due to demands and business competition, this product still happens even though some people regret it.

This product involves at least three parties, the cardholder (hamil bithaqah), the card issuer/Islamic bank (mushdir bithaqah), and the merchant (qabil bithaqah). These three parties are tied up with three contracts at once, kafalah, qardh, and ijarah. In kafalah, for example, the Card Issuer is the guarantor for the Cardholder towards the Merchant for all payment (dayn) obligations arising from transactions between the Cardholder and the Merchant, and/or cash withdrawal from another bank or ATM. In this contract, the card issuer 
may receive a fee (ujrah kafalah). In regard to qardh contract, the Card Issuer is the lender (muqridh) to the Cardholder (muqtaridh) for cash withdrawal from the bank or ATM which belongs to the card issuer. At last, in Ijarah contract, the Card Issuer is a provider of payment and service system for the Card holder. Here, the Card holder is subject to membership fee.

The income generated by the Islamic banking includes membership fee, merchant fee, cash withdrawal fee, and kafalah fee. These fees must be clearly set when the card application is agreed, except for merchant fee. When the card holder makes a transaction in the merchant, kafâlah wal ijârah contract is applied. Theoretically, the ijârah contract is a lease agreement by the card holder for facility provided by the card issuer. In the meantime, if the cardholder makes a cash withdrawal, then qardh and ijârah contracts are implemented.

Overall, all is legalized as long as it doesn't encourage usury, wastefulness, and unlawful transactions or contradicts the Sharia provisions and causes endless indebtedness (ghalabah al-dayn).

\section{F. Optimizing Profit Sharing}

In countries implementing two banking systems (conventional and Islamic banks) or where Islamic banking is considered as a minority system, they have encountered many obstacles to apply Sharia principles. Such obstacles include legislation, jurisdiction, Sharia regulations, documentation, and money laundry. One example of the obstacles is the ban for Islamic banking to provide goods financing in which the banks as providers are illegitimated because the merchant plays the role here, not the bank. (Hassan, 2011) The Islamic banking claims to avoid usury. However, it generally conducts debt-based financing and gives a guarantee for its customers to have a stable profit. (Siddiqui, 2010) Consequently, it is assumed the financing in Islamic banking is similar to that in conventional banking due to a fixed interest rate.

The above Murabaha, pawning, and hajj financing practices can justify the assumption, especially for those who do not know the features and procedures of Sharia regulations. Practically, the Islamic banking sometimes takes advantage of the National Sharia Council's opinions and decisions to support its interests regardless they are right or wrong. Under these conditions, the council should refuse to serve the Islamic Financial Institutions instead of God. If it is for the right interests, including in the case of halal and haram, then the council truly plays its roles. (al-Misri, 2008) Istihsan and maslahah are the methods used by modern thinkers to determine the terms and conditions of modern financial transactions, such as futures options and swaps to eliminate acceptable levels of gharar and avoid conflicting parties. (AlSaati, 2003) Here, the National Sharia Board also applies such methods and conducts the objective determination method (tahqiq al-manath) as well as reviews the opinions from the classical Ulema (i'adat al-nazhar).

In terms of multi contract, the National Sharia Board adopts it for many Islamic financial products. Concerning the ban of such contract, its fatwa attempts to avoid it to be separated from the contracts that build it or use a promise as a separator of two or more contracts. To this end, multi contract is perceivably spared from the prohibition of the Hadith concerning bay'atayn fi bay'ah and shafqatayn fi shafqah in which Ibn al-Qayyim means by: "I sold this item to you for a hundred for one year on one condition that I will buy it again from you for eighty in cash". (al-Qaradhawi, )

Other Islamic Financial Institutions also meet challenges for implementing Sharia totally. Islamic insurance is still involved in non-Islamic activities as it reinsures over the conventional insurance and its investments do not entirely comply with the Sharia provisions. (Qureshi, 2011) Here, the Islamic banking should avoid modifying the sale and purchase contract of ordinary goods into financing by credit system. This modification places the risk of goods upon the seller and the risk of debt to the bank. This is exactly what happens in conventional banking. (Lewis, 2008) In the process, the Islamic Financial Institutions are required to be committed to running the Sharia. Additionally, the States with Muslim majority must also be able to answer the critics concerning their seriousness in promoting profit and loss sharing model which becomes the main pillar in Islamic banking.

Actually, the profit-sharing system has been widely practiced by the societies in Indonesia. Communities of farmers and traders have practiced what is known as maro or mertelu system (profit sharing system). This means Indonesia which is recognized to apply Islamic, civil, and customary laws can combine these three systems in responding to Islamic financial products. Therefore, the profit sharing in Islamic law (mudaraba), cooperation in civil law, and maro or mertelu system in customary law should meet and become the typical sharing model in Indonesia. In that way, the implementation of profit-sharing system becomes easier and more desirable for the community.

\section{CONCLUSION}

The implementation of multi contract in Islamic banking products has largely conformed to the provisions required by Sharia. However, there are issues in the fatwa by the National Sharia Board, Indonesian Ulema Council, which are not in accordance with the provisions. Theoretically, usury is prohibited, but in practice it still appears. This seems to happen in the Hajj financing product which consists of two contracts, ijarah and qardh (bailout). Until now, the Islamic banking has set ujrah (fee) based on the amount of bailout provided by the banks for their customers, whereas the provisions of the fatwa have restricted such setting which is based on qardh. Hajj financing arrangement is a service in which its process applies for everyone. Therefore, the imposition of fee to each of them must also be the same although the amount of bailout is different. This happens because the fee is generated from ijarah contract, not qardh contract. 


\section{REFERENCES}

[1] This study refers to a summary of research funded by the Faculty of Sharia and Law, 2014

[2] Saeed considers that there is a tendency to understand that every additional to the principal is usury. According to him, the essence of forbidden usury is riba of injustice and injustice. Abdullah Saeed, Islamic Banking and Interest: A Studi of Riba, translated. (Jakarta: Paramadina, 2004), first edition, p. 193.

[3] An interview with Ziyad, Syariah Compliance Bank Danamon Syariah, on August 9, 2010

[4] An interview with Ahmad Yani, Syariah Compliance Bank Negara Indonesia Syariah, on August 13, 2010

[5] Riba nasiah is giving a surplus or extra amount due to delay of delivery. More specifically, riba nasi'ah arises in loan transactions (on the basis of future repayment of more than the principal) as well as sale transactions (on the basis of deferred price). Rahmat Syafe'i, Fiqih Mu'amalah, (Bandung: Pustaka Setia Bandung), p. 262-264

[6] Hawâlah is a debt-shifting contract from one party owed to another who is obliged to bear (pay) it

[7] Wakâlah bil ujrah is one form of wakâlah contracts in which the customer gives authority to the insurance company in exchange for ujrah (fee)

[8] al-'Imrâni, Abdullâh bin Muhammad bin Abdullâh. (2006). Al-'uqûd alMâliyah al-Murakkabah: Dirâsah Fiqhiyyah Ta'shîliyah wa Tathbîqiyyah. Riyadh: Dâr Kunûz Eshbelia li al-Nasyr wa al-Tauzî’. first Edition.

[9] Al-Mawardi, al-Hawi al-Kabir, vol.1.

[10] al-Misri, Rafiq Yunus, (2008). "'Amal al-Fuqaha' lada Rijal al-Amwal wal-A 'mal", Jurnal Ekonomi Islam Universitas King Abdul Aziz, Vol.21, No. 1 .

[11] Al-Muzaniy, Mukhtashar al-Muzaniy, (bi-Hâmisy al-Umm), Vol. 2.

[12] Al-Saati, Abdul-Rahim, (2003). "The Permissible Gharar (Risk) in Classical Islamic Jurisprudence", Jurnal Ekonomi Islam Universitas King Abdul Aziz, Vol.16, No. 2.

[13] al-Zuhaili, Wahbah, (1987). al-Fiqh al-Islami wa Adillatuh. Beirut: Dar al-Fikr. Vol.4.

[14] An interview with Ziyad, Syariah Compliance Bank Danamon Syariah, on August 9, 2010.

[15] An interview with Ahmad Yani, Syariah Compliance Bank Negara Indonesia Syariah, on August 13, 2010

[16] An interview with Ahmad Yani, Syariah Compliance Bank Negara Indonesia Syariah, on August 13, 2010.

[17] Antonio, Muhammad Syafi'i, (2001). Bank Syariah dari Teori ke Praktik. Jakarta: GIP.

[18] Bank Indonesia Derektorat Perbankan Syari’ah “Kamus Istilah Keungan dan Perbankan Syari'ah" (Jakarta : BI, 2006).

[19] Dewi, Gemala. (2006). Aspek-Aspek Hukum dalam Perbankasn dan Peransuransian Syariah di Indonesia. Kencana, Jakarta.

[20] DSN dan BI, (2003). Himpunan Fatwa DSN. Jakarta: DSN dan BI.
[21] Hammâd, Nazîh. (2005). al-'uqûd al-Murakkabah fỉ al-Fiqh al-Islâmy. Damaskus: Dâr al-Qalam. first edition.

[22] Hassan, Rusni, Aishath Muneeza and Ismail Azzam Wajeeh, (2011). "Legal Obstacles Facing Islamic Banking in Malaysia", World Journal of Social Sciences, Vol. 1, No. 5.

[23] Ibn al-Qayyim. (1955). I'lam al-Muwaqqi'în 'an Rabb al-'Âlamin. Beirut: Dâr al-Fikr. Vol. 1.

[24] Ibn Hanbal, Imam Abu Abdillah Ahmad. (1414 H). Musnad Ahmad, j. 2. Beirut: Dâr al-Ihyâi al-Turâts al-'Araby. Third Edition.

[25] Ibnu Rusdy, Bidayatul Mujtahid wa nihayatuhu, (Beirut, Muqtasid Darul Qalam, 1988) V.II.

[26] Kasmir, (2002). Bank dan Lembaga Keuangan Lainnya. Jakarta: PT. Rraja Grafindo Persada.

[27] Kasri, Rahmatina A. and Salina Hj. Kassim. (2009). "Empirical Determinants of Saving in The Islamic Banks: Evidence from Indonesia", Jurnal Ekonomi Islam Universitas King Abdul Aziz, Vol.22, No. 2.

[28] Kuran, Timur. (1986). "The Economic System in Contemporary Islamic Thought: Interpretation and Assessment", International Journal of Middle East Studies, Vol. 18, No. 2.

[29] Lewis, Mervyn K. (2008). "In what ways does Islamic banking differ from conventional finance?", Journal of Islamic Economic, Banking, dan Finance, Vol. 4, No. 3.

[30] Maksum, Muhammad. (2013). Fatwa Ekonomi Syariah di Indonesia, Malaysia, dan Timur Tengah. Jakarta: Balitbang dan Diklat Kemenag RI.

[31] Maksum, Muhammad. (2015). "Economics Ethics in the Fatwa of Islamic Economics”, Jurnal Al-Ulum, Vol. 15 No.1.

[32] Maksum, Muhammad. (2014). "Model-Model Kontrak dalam Produk Ekonomi Syariah”, Jurnal Al-'Adalah (Jurnal Hukum Islam), Vol. XII No. 1.

[33] Mannan, M. Abdul, (1997). Teori dan Praktek Ekonomi Islam. Dana Bhakti Wakaf.

[34] Qureshi, Asif Ahmed, (2011). "Analysing the Sharia Compliant Issues Currently Faced by Islamic Insurance", Interdiciplinary Journal of Contemporary Research in Business, Vol. 3, No. 5.

[35] Saeed, Abdullah. (2004). Islamic Banking and Interest: A Studi of Riba, translated. Jakarta: Paramadina. first edition.

[36] Schoon, Natalie. (2008). "Islamic Finance-An Overview", European Business Organization Law Review 9.

[37] Siddiqui, Shamim Ahmad, (2010). "Establising the Need and Suggesting a Strategy to Develop Profit and Loss Sharing Islamic Banking", Journal of Islamic Economic, Banking, dan Finance, Vol. 6 No. 4.

[38] Spells, Sarah, (2009). "Researching Islamic Law: an Introduction", Legal Information Management, 9.

[39] Syafe'i, Rahmat, (1997). Fiqih Mu'amalah. Bandung: Pustaka Setia Bandung.

[40] Tim Penyusun. (1996). Kamus Besar Bahasa Indonesia. Jakarta: Balai Pustaka. Second Edition.

[41] ' Sarah Spells, "Researching Islamic Law: an Introduction", Legal 